\title{
Impact of strategy, HRM Strength and HRM bundles on innovation performance and organizational performance
}

\author{
Rita Campos e Cunha ${ }^{1}$ \\ Associate Professor \\ Faculdade de Economia, \\ Universidade Nova de Lisboa \\ rcunha@fe.unl.pt

\section{Miguel Pina e Cunha} \\ Associate Professor \\ Faculdade de Economia, \\ Universidade Nova de Lisboa
}

July, 2004

\footnotetext{
${ }^{1}$ This paper represents work in progress. The author acknowledges CRANET-E network, for the data provided.
} 


\begin{abstract}
This study uses structural equation modeling to test a model of the impact of human resource management bundles on perceived organizational performance and innovation performance, on a large sample of companies. Strategic management orientation and innovation as a strategic factor are proposed to influence the existence of two types of HR bundles, functional flexibility and performance management, as well as contributing to stronger HR systems. HRM Strength, which integrates the 'metafeatures' of an HRM system and provides a common interpretation of organizational goals, has a strong positive impact on both innovation and organizational performances. Finally, while both the functional flexibility and performance management bundles have a positive impact on organizational performance, they do not seem to affect innovation performance.
\end{abstract}




\section{Introduction}

The impact of innovation on organizational results has been generally demonstrated in empirical studies (Damanpour, Szabat and Evan, 1989; Khan and Manopichetwattana, 1989; Nayak, 1991; Utterback, 1994), but relatively little attention has been paid to the extent to which HRM practices may positively contribute to innovation performance.

On the other hand, different studies have emphasized the contribution of Human Resource Management practices to firm performance. The focus of these studies has been moving from the impact of several specific HRM practices, such as compensation (Gerhart \& Trevor, 1996; Gomez-Mejia, 1992), training (Bartel, 1994) or performance management systems (McDonald \& Smith, 1995), to reporting the positive impact of progressive HRM practices on organizational performance (Delaney \& Huselid ,1996; Huselid, 1995, Cunha et al, 2003). In this latter approach, there is a shared idea that HR practices are only effective when complementarities, or bundles, are considered, including training, incentive systems, high selectivity, flexible job assignments and performance management. These practices, in concert, contribute to improve employee and company performance, namely by increasing the level of productivity (Ichniowski et al, 1997), financial performance or innovation (Laursen \& Foss, 2003).

Although this line of research has demonstrated a significant impact of HR practices, the features of the process through which the HR system helps employees in making sense of what is expected from them have not been well addressed and Bowen and Ostroff (2004) propose that this shared meaning represents the "strength of the HRM system". This construct represents a set of process characteristics that send an effective message about HRM content to all employees, clarifying what strategic goals are important and what employee behaviors are expected and rewarded.

In the remaining of this article, a model is developed, in which HRM practices and HRM strength are integrated, in order to contribute to innovation and organizational performance. The model is tested using structural equation modeling on a sample of 1822 companies and data from the 1999/2000 CRANET survey on International Strategic Human Resource Management. 
The contribution of this paper to the literature is twofold. First, the model tested is a new integration of several levels of analysis, i.e., the corporate strategic level, the functional HRM level, the fit and congruence of strategy and HRM practices and the consequences in terms of organizational performance. Content and process are analysed in this study. The second contribution is to demonstrate the impact of the strength of the HRM system on firm performance.

In the remaining of this article, we will review the literature linking HRM practices to both innovation and organizational performances. The model will then be developed. In the subsequent sections the empirical results are presented and conclusions and limitations of the study will be discussed.

\section{Literature Review}

\section{HRM and Innovation}

Innovation is an important means of survival in the face of the dynamic nature of competitive environments (Han, Kim and Srivastava, 1998), a form of organizational adaptation that has been propelled by several external forces: technological developments, deregulation, globalization, shortening of innovation cycles and new buyer needs (Cunha and Verhallen, 1998). Organizational innovation is, therefore, intended to improve effectiveness as organizations respond to changes in their internal and external environments, or even to change the environments with their innovative/entrepreneurial activities (Cunha et al, 2004). Furthermore, some research, dealing with the strategic role of innovation, focuses on quality management as a strategic aspect that supports the management of innovation (Kanji, 1996, Bossink, 2000). The quality management procedures are expected to become particularly relevant to face the needs for product/service customization and customer service, which may also promote and support innovation.

What organizational characteristics may enhance the level of innovation is certainly an important line of inquiry, where the HRM system and human capital may be included. Considering the above-mentioned supportive role of quality management, the interaction practices that emphasize cross-functional management, empowerment, leadership and cooperation have been included in this group of innovation enhancing variables (Bossink, 2000). 
Two of the HR practices under scrutiny in this literature have been training and flexibility. Arulampalam \& Booth (1998), using the British Household Panel Survey 1991-95, concluded that workers on short-term employment contracts are less likely to get any training and suggest a trade-off between the expansion of contingent contracts and the proportion of skill development. In addition, some research indicates that the benefits of employee and managerial training can only be fully accomplished if training is accompanied by organizational restructuring and changes in work practices (Lam, 1996), which stresses the need for analyzing HRM practices in a systemic fashion, i.e., by considering bundles of complementary practices (Laursen \& Foss, 2003).

Employment contract flexibility has also been looked at from diverse theoretical perspectives - strategy, HRM and economics, offering different insights on the subject. The resource-based view of the firm (Barney, 1995) proposes that innovation performance results from the development of organizational capabilities and resources, and that innovation is path-dependent, emerging from prior experimentation and learning (Pavitt, 1991). The resource-based view argues that emphasis on secure, long-term employment contracts, is more conducive to innovation. This position is consistent with the HR literature (much of which is affiliated with the resource-based view) that suggests the High Performance Work Systems to positively affect employee productivity, creativity and discretionary effort, which drive profits, growth and market value (Becker et al, 1997). The general premise in this literature is that innovation and quality of service is supported by employment practices that stress a long-term stake in an organization (Storey et al, 2002), although these authors suggest that in the UK, the increase of flexible contingent labor has occurred in parallel with the increased emphasis on innovation, and in a relatively decoupled way from the actual pursuit and achievement of innovation, that is, as companies emphasize innovation as a strategic factor, they are increasing the proportion of contractual flexibility.

In contrast to flexibility achieved by contingent employment contracts, firms may develop flexibility associated with breadth of employee skills and behavioral repertoires. In this case, organizational flexibility "stems from the availability of a vast repertoire of behavioral scripts among employees" (Wright \& Snell, 1998: 765), allowing innovation to emerge from prior experimentation and learning. As employees possess a wider variety of skills and behavioral repertoires, firms can adapt to changing environments faster and easier (Wright \& Snell, 1998) and 
achieve a better innovation performance. Training clearly helps build this behavioral flexibility, but so do some internal mobility practices and career management practices, such as job rotation or temporary assignments (Laursen \& Foss, 2003).

We can therefore propose that a set of HR practices (bundle), composed of functional flexibility enhancement and training and skill development, is particularly likely to promote employee competencies that lead to better organizational innovation performance. Hence,

Hypothesis 1: the functional flexibility $H R$ bundle, which includes training and other practices that promote functional flexibility, will lead to better innovation performance.

Other HRM practices that can influence the behavioral resource flexibility, besides learning, internal mobility or job enrichment, are performance appraisal and variable pay systems, because they clarify organizational goals and reward their achievement. To the extent that appraisal and compensation systems can motivate skilled employees to engage in broader behavioral patterns, the firm's innovation performance is improved (Laursen \& Foss, 2003). Thus, the second hypothesis:

Hypothesis 2: the performance management bundle, composed of performance appraisal and variable pay, will lead to better innovation performance.

\section{HRM and Organizational Performance}

In the last decade, research has shown that HRM practices contribute to organizational performance. The focus of this literature has been changing though. Early studies emphasized the impact of several separate HRM practices, such as compensation (Gerhart \& Trevor, 1996; Gomez-Mejia, 1992), training (Bartel, 1994) or performance management systems (McDonald \& Smith, 1995).

Later studies reported the positive impact of progressive HRM practices on organizational performance (Delaney \& Huselid, 1996; Huselid, 1995) as well as the virtuous impact of HR sophistication, measured by investments in HR planning, in hiring and in employee development on labor productivity, particularly in capital intensive organizations (Koch \& McGrath, 1996). Studies in this latter approach, have in common the idea that a bundle of HR practices improves 
employee and company performance, due to the reinforcing and complementary relationships that exists between these practices.

Several interpretations may account for this impact. First, the overall set of HRM practices contributes to the development of employee skills and ability, motivation and work organization (Delaney \& Huselid, 1996). There is a shared view that High Performance Work Systems, which include training, incentive systems, high selectivity, flexible job assignments and performance management, in concert, contribute to improve employee and company performance, namely by increasing the level of productivity (Ichniowski et al, 1997), and having an impact on the 'bottom line' (Huselid, 1995; MacDuffie, 1995; Cunha et al, 2003).

A second perspective is anchored on the strategy literature and stresses the complexity of HRM practices, which leads to inimitability by competitors (Barney, 1991) as well as 'fit', both vertical and horizontal (Wright \& Snell, 1998). Two types of links have been proposed by Wright and Snell (1998) to have impact on firm performance: the link between strategy and skills and the link between strategy and behaviors. While the Functional Flexibility bundle, defined in this study, matches the first link, the Performance Management bundle reflects the second one. Hence:

Hypothesis 3: the functional flexibility $H R$ bundle, which includes training and other practices that promote functional flexibility, will lead to better organizational performance.

Hypothesis 4: the performance management bundle, composed of performance appraisal and variable pay, will lead to better organizational performance.

\section{Strength of the HRM System}

The literature presented above uses a macro approach to defend the links between HRM features and outcomes at firm level, such as productivity, financial performance or innovation. HRM creates the conditions to achieve strategic organizational goals, by influencing employee attributes (competencies and behaviours). However, according to Bowen and Ostroff (2004), it does not address the issue of how the HRM system can contribute to performance by motivating employees to adopt the desired behaviors and attitudes, i.e., the process. These authors differentiate two features of an HRM system that will jointly contribute to performance, e.g. content and process. Whereas content 
refers to the individual practices intended to achieve particular objectives, such as promoting innovation, process deals with how the HRM system is designed and administered to send signals to employees that allow them to create a shared meaning about the "desired and appropriate responses and form a collective sense of what is expected" (Bowen \& Ostroff, 2004: 204). This shared meaning represents the strength of the HRM system and refers to the extent to which uniform (versus ambiguous) expectancies regarding the appropriate response patterns are induced. The congruent array of training programs, compensation practices, team building, job enrichment or appraisal, providing clear statements of behaviors that are expected, supported and rewarded, can affect organizational behavior (Schneider, Brief \& Guzzo, 1996) and lead to the achievement of organizational goals.

Using Kelley's attribution theory, Bowen and Ostroff (2004) propose that the HRM system will create a strong situation if it is perceived as high in distinctiveness, consistency and consensus. Distinctiveness refers to capturing attention and arousing interest and is associated with visibility, understandability, legitimacy of authority and relevance of the HRM practices. Consistency refers to the establishment of consistent relationships over time, people and contexts while consensus results when there is agreement among employees in their view of the event-effect relationship.

Strength of the HRM system will promote a shared meaning of the situation among employees, consistent with strategic organizational goals, and for that reason is expected to have a direct impact on organizational results.

Our next hypotheses are, therefore:

Hypothesis 5: A strong HRM system will lead to better innovation performance.

Hypothesis 6: A strong HRM system will lead to better organizational performance.

\section{Strategic Management Orientation and Innovation as a Strategic Goal}

Organizational goals can be expected to derive from the exercise of strategic planning, through which relevant environmental and internal conditions are analyzed and opportunities and threats anticipated. Positive correlations have been reported between planning formality and firm performance (Lyles et al, 1993), because there will be a greater emphasis on the process of strategic 
decision-making, particularly in identifying distinctive competencies, resource deployment and monitoring. At the same time, as Tregaskis (1997) has reported, formalized HR strategies increase the likelihood of the adoption of High Performance Work Systems. In this study, the existence and the formalization of a mission, corporate strategy and HRM strategy are used as indicators of Strategic Management Orientation. So, we hypothesize that Strategic Management Orientation will affect the degree to which the HRM bundles are implemented, as well as the Strength of the HRM System:

Hypothesis 7: Strategic Management Orientation will lead to a stronger Functional Flexibility bundle.

Hypothesis 8: Strategic Management Orientation will lead to a stronger Performance Management bundle.

Hypothesis 9: Strategic Management Orientation will lead to a stronger HRM System.

Since this study is particularly interested in looking at the innovation performance, we also predict that when companies pursue a competitive strategy based on innovation, the Functional Flexibility and Performance Management bundles will assume higher importance. In fact, O'Brien (2003) has reported that firms with innovation as a strategic factor maintain a relatively higher level of financial slack, in order to support this strategy, by allowing continuous investment in R\&D activities, availability of funds to launch new products and investment in knowledge base expansion. In addition, Cottam, Ensor \& Band (2001) have found, in a study of the FTSE 100 to analyze whether innovation was being considered at a strategic level within organizations, that a small minority of UK companies has invested in personnel with responsibility for innovation and they suggest that innovation be given a strategic direction, with the development of specific metrics for the subject and the freedom from traditional hierarchical structures.

We therefore suggest that:

Hypothesis 10: Innovation as a Strategic Factor will lead to a stronger Functional Flexibility bundle.

Hypothesis 11: Innovation as a Strategic Factor will lead to a stronger Performance Management bundle. 
Hypothesis 12: Innovation as a Strategic Factor will lead to a stronger HRM System.

\section{The Model}

The model presented in Figure 1 represents the hypotheses stated above.

Insert Fig. 1 here

According to this model, Strategic Management Orientation, or the extent to which organizations develop mission, strategy and HR strategy statements, and Innovation as a Strategic Factor, or the degree to which innovation and quality are important product/service characteristics for the competitive success, are two exogenous variables that are expected to have an indirect impact on innovation and organizational performance through their impact on the development of a strong HRM system and on the existence of specific HR bundles: the Performance Management bundle, which includes performance appraisal and variable pay, and the Functional Flexibility bundle, which includes functional flexibility and skill development. The strength of the HRM system is expected to have a direct impact on Perceived Innovation and Organizational Performances, but also an indirect impact, through the HRM bundles. Finally, the two HRM bundles are expected to have a direct impact on both types of perceived performance. All these impacts are expected to be positive.

In the next section, the sample, measures and analysis will be be presented.

\section{Method}

\section{Sample}

The model introduced above was tested using the 1999/2000 survey on strategic HRM, developed by the CRANET-E Network. This is an international survey, which contains organizational information on the strategic human resource management of companies in 28 countries, mostly European. The same questionnaire has been used in all countries, after translation and back translation by a local team in each of the participating countries. Questionnaires are addressed to the senior HR manager of each company. 
The survey is divided into six sections covering the personnel/human resources function, staffing practices, employee development, compensation and benefits, employee relations and communication and organizational details (for further details see Brewster, Mayrhofer \& Morley, 2004).

A total of 9119 filled questionnaires were received, with a $17 \%$ response rate. As in past editions of the survey, there was some variation in response rates across countries, ranging from over $90 \%$ in Greece, where there was a previous telephone contact with companies, to $4 \%$ in Israel. Variations in data collection strategies as well as different attitudes towards surveys and disclosure of organizational details across countries may account for these differences.

To test the model in this study, the sample was restricted to private sector companies in the services and manufacturing sectors, with no missing data on any of the measures.

The final sample has 1822 organizations. The average size by number of employees is 2271 employees, ranging from 6 to 710000 and a median of 500 . Tables 1 and 2 present the distribution of companies by country and by industrial sector.

\section{Measures}

The overall measurement model employs 62 measures for the 7 constructs. Two of the constructs are exogenous factors in the model, related to organizational strategy - strategic management orientation $\left(\xi_{1}\right)$ and innovation as a strategic factor $\left(\xi_{2}\right)$. The other five are endogenous factors - HRM strength $\left(\eta_{1}\right)$, functional flexibility bundle $\left(\eta_{2}\right)$, performance management bundle $\left(\eta_{3}\right)$, perceived innovation performance $\left(\eta_{4}\right)$ and perceived organizational performance $\left(\eta_{5}\right)$.

Strategic Management Orientation was measured by three questions in the survey regarding the existence of a mission statement, a corporate strategy and a personnel/HRM strategy, on a 1 to 3 scale ( 1 - no; 2 - yes, unwritten and 3 yes, written). Each of these three variables was transformed into two dummy variables: existence ( 0 - no; 1 - yes) and formalization ( 0 - unwritten; 1 written). The latent variable is therefore measured by six dummy variables.

Innovation as a Strategic Factor was measured by four questions in the survey regarding the importance of quality, customisation, service and innovation for organizational competitive success. These four items were included, given the 
arguments that quality management, which promotes customisation and customer service, has a supportive role for innovation (Kanji, 1996; Bossink, 2000). A 1 to 4 scale is used, where 1 is very important, 2 is relatively important, 3 not important and 4 not applicable. Each of these four questions was transformed in two dummy variables: importance (1 - important, including answers 1 and 2 and 0 - not important, including answers 3 and 4) and level of importance ( 1 - very important, 0 - relatively important and not important).

HRM Strength was measured by 17 indicators. The first 14 resulted from transforming each of seven questions of the questionnaire into two dummy variables. These questions asked whether the organization had a policy for the following HR areas: salary and benefits, recruitment and selection, training and development, communication with employees, equal opportunity/diversity, flexible work practices and management development. Each of these seven variables was transformed into two dummy variables: existence (0 - no; 1 - yes) and formalization ( 0 - unwritten; 1 - written). The fifteenth question refers to systematic evaluation of HR department's performance, with yes (1) or no (0) alternatives. The sixteenth indicator concerns the criteria used for the evaluation of the HR department's performance - internal cost efficacy measures, cost benchmarking and performance versus objectives. Each item is answered yes (1) or no (0). The sum of the three answers constitutes this indicator. The seventeenth indicator concerns the involvement of the HR manager or director in strategic development, on a 0 to three scale, where 0 is not involved, 1 means involvement in implementation only, 2 , involvement by consultation and 3 means involvement from the outset.

The Functional Flexibility Bundle was measured by 19 indicators. The first six items were questions about existence (0 - no, 1 - yes) of formal career plans, assessment centers, succession planning, planned job rotation, "high flyer plans" for managers and international appointments for managers. Four items inquired whether there was a change in the last three years, in job specification for managers, technical/professional, clerical and manual staff, in order to make them wider and more functionally flexible ( 0 - no, 1 - yes). The eleventh item was a question on the systematic analysis of employee training needs $(0-$ no, 1 yes). The next five items concern the sources used for training needs analysis: business plan, training audits, line management requests, performance appraisal and employee requests, on a 1 to 4 scale ( 1 - never, 4 - always). The seventeenth and eighteenth indicators focus on frequency of training evaluation, 
immediately after training and some months after training (1 - never, 4 - always). The nineteenth item deals with the number of performance evaluation criteria used, ranging from 0 (no criteria used for evaluation, to 4 . The four criteria proposed are learning, as assessed by a test, behavioral changes, results (changes in organizational performance) and employee reaction.

The Performance Management Bundle was assessed through 7 items. The first indicator, ranging from 0 to 4 , is a sum of four dummy variables on existence of performance appraisal for managers, technical/professional, clerical and manual staff. The second indicator, termed multisource feedback, represents the sum of participants in the performance appraisal procedure (immediate superior, next level superior, the employee, subordinates, peers, customers and others) ranging from 0 to 7 . The third item refers to the number of performance appraisal uses (individual training needs, organizational training needs, promotion potential assessment, career development, pay-for-performance and work organization), ranging from 0 to 6 . Fourth to seventh items indicate how many types of different incentives the company gave to managers, technical/professional, clerical and manual staff. Four types of incentives were mentioned in the questionnaire, for respondents to check all applicable: employee share options, profit sharing, bonus and merit pay. We have, as a consequence, four indicators, ranging from 0 to 4 .

Perceived Innovation Performance was measured by three manifest variables, which rated organizational performance against that of relevant competitors in terms of service quality, product to market time and rate of innovation. A 0 to 3 scale was used, where 0 - not applicable, 1 - lower half, 2 - higher half and 3 - top $10 \%$.

Perceived Organizational Performance was measured by two questions. One of the items asked respondents to rate organizational performance against that of relevant competitors in terms of profitability, on a scale of 0 to 3 , where 0 - not applicable, 1 - lower half, 2 - higher half and 3 - top 10\%. The second indicator is a question on company's perceived gross revenue over the past three years, on a five-point scale (1 - so low as to produce large losses, 2 - insufficient to cover costs, 3 - enough to break even, 4 - sufficient to make a small profit and 5 - well in excess of costs).

The two last latent variables - Innovation Performance and Organizational Performance are subjectively measured, which may be justified by the fact that 
objective performance measures of organizational performance in studies that use international surveys within a number of different countries are dangerous, given the differences between long-term and short term cultural orientations and differing tax and fiscal regimes, that may bias the financial statements and therefore, make them noncomparable (Lahteenmaki \& Vanhala, 1998; Martell \& Carroll, 1995). In addition, strong correlations between subjective responses and objective measures of organizational performance have been found (Pearce et al, 1987).

In Table 3, reliability coefficients (Cronbach's alpha) are presented for the seven latent variables. All variables in the model are at acceptable levels of reliability, although three constructs - Perceived Organizational Performance, Innovation as a Strategic Factor and Strategic Management Orientation are below the 0.7 cutoff. However, Nunnally (1967:226) considers a range of 0.5 to 0.6 to be acceptable for preliminary research and Murphy \& Davidshofer (1988: 89) state 0.6 to be the cutoff for an unacceptable level.

\section{Analysis}

The structural model proposed was tested using AMOS 4.0 (Arbuckle \& Wothke, 1999), to generate maximum likelihood parameter estimates through the analysis of the matrix of covariance among variable scores. Model fit was assessed using three fit indices: Goodness of Fit (GFI), Adjusted Goodness of Fit (AGFI) and the Root Mean Square Error of Approximation (RMSEA). This last index includes parsimony as a criterion in the estimation of fit, and therefore penalizes for inclusion of additional paths. GFI and AGFI values greater than 0.9 are generally considered to indicate a good fit. Values of RMSEA below 0.08 indicate a reasonable fit, and those below 0.05 indicate good fit to the data (Browne \& Cudeck, 1993).

\section{Results}

As shown in Table 4, all nonfixed indicator loadings for each latent variable are significant at the 1 percent level. 
Insert Table 4 here

The estimated model exhibits a satisfactory fit: $G F I=0.91, A G F I=0.89$, $R M S E A=0.03$. The model may, therefore, be considered valid in general terms. However, three of the hypotheses were not confirmed by the estimated parameters, as shown in Figure 2 and Table 5.

Insert Figure 2 here

Insert Table 5 here

Analysis of results leads us to accept the hypotheses that HRM Strength does significantly and positively affect both innovation performance and perceived organizational performance $-\mathrm{H}_{5}$ and $\mathrm{H}_{6}$. This impact is particularly strong for innovation performance.

On the other had, Innovation as a Strategic Factor and Strategic Management Orientation will positively affect the Strength of the HRM System, which supports hypotheses $\mathrm{H}_{9}$ and $\mathrm{H}_{12}$. The strongest relationship in our model is the one of Strategic Management Orientation on HRM Strength.

The impacts of Strategic Management Orientation on the Functional Flexibility Bundle and the Performance Management Bundle were supported by the estimated parameters $\left(H_{10}\right.$ and $H_{11}$, respectively), as well as the impact of Innovation as a Strategic Factor on the Functional Flexibility Bundle $\left(\mathrm{H}_{7}\right) . \mathrm{H}_{4}$, which stated a positive impact of the Performance Management Bundle on Perceived Organizational Performance, and $\mathrm{H}_{3}$, which proposed a positive impact of the Functional Flexibility Bundle on Perceived Organizational Performance, were both supported at the 1 percent significance level. 
Three hypotheses were not supported by the data: $\mathrm{H}_{1}$ and $\mathrm{H}_{2}$, which proposed positive impacts of the Functional Flexibility and Performance Management Bundles on Innovation Performance were not statistically significant. The Performance Management Bundle had even a negative impact, although not significant. Finally, $\mathrm{H}_{8}$ proposed a positive impact of Innovation as a Strategic Factor on the performance Management Bundle and was not supported.

In summary, the results show HRM Strength as having an important effect on Organizational Performance and Innovation Performance. HRM Strength was, actually, the only variable with a significant positive impact on Innovation Performance. None of the HR Bundles proved to positively affect Innovation Performance. Organizational Performance, in general, receives the positive impact of the HR Bundles.

\section{Discussion and Conclusion}

This study is an attempt to demonstrate the impact of HRM practices on organizational performance. Particularly, it was intended to analyze how HRM may leverage innovation. Literature in Strategy emphasizes innovation as a major differentiator for organizations and a critical factor for organizational growth and competitive advantage. Since innovation occurs over time, by people engaged in transactions with other people, in an institutional context (Van de Ven, 1986), it makes sense to consider those HRM practices that enhance knowledge creation and sharing as critical factors for improving innovation results in an organizational context. However, the role of external networks, such as professional associations, to facilitate the diffusion and adoption of new ideas, through boundary spanning activity, has not been considered in this model. We only focused on the internal context, particularly in terms of training and development, functional flexibility, performance appraisal and feedback and variable pay.

This argument may be an explanation to the lack of empirical support for the hypotheses regarding impact of HRM bundles on innovation performance, which is reinforced by the positive and strong impact that strength of the HRM system has been shown to have. Innovation is increasingly dependant on networking across multiple "communities of practice" (Scarbrough \& Corbett, 1992) within and across organizations. Linkages to users or suppliers, or to knowledge 
institutions, such as universities or consultancies, have been found to be conducive to innovation (Laursen \& Foss, 2003), but were not considered in this model. Knowledge and skills, however, cannot be simply transferred through networks, and a 'common stock of knowledge' (Kogut \& Zander, 1992), needed to facilitate the transfer process and knowledge, therefore, depends on a process of interrelating and sense making (Weick, 1993). The strength of the HRM system (Bowen and Ostroff, 2004) has been argued to account for this sensemaking, for sending strong signals about organizational goals and strategic orientation, as well as providing employees with behavioural expectations and instrumentalities.

In this study, individual determinants of innovation have not been included in the model, such as quality of the superior-subordinate relationship or any other type of leadership effect, career stage, problem-solving style or work group relations, which have been shown to support innovation (Scott \& Bruce, 1994). Task characteristics and structure design were equally not included. Not including these variables may additionally account for the lack of support of the hypotheses that concerned HR determinants of organizational innovation performance.

This study provided support for the argument that HR complementary practices are important determinants of general perceived organizational performance. A previous model (not reported here) was tested where HR practices were not organized in coherent bundles, which did not have an adequate fit and most path coefficients were non significant. Previous research (Cunha et al, 2003) has focused on the impact of market forces, such as competitive intensity and industry attractiveness on the firms' strategic management orientation and organizational performance. With this study, the aim was to focus on the firm and on how it's strategic orientation may affect the HR practices. Our results show that while strategic management orientation does have an impact on the HR bundles, the same did not apply when considering innovation as a strategic factor: the performance management bundle was not affected by this strategic intent. However, the functional flexibility bundle was significantly affected by innovation strategy, which supports the notion that skill development and build-up of employee behavioral scripts are a major concern for companies that compete through innovation (Arulampalam \& Booth, 1998, Storey et al, 2002).

A major contribution of this study lies in the demonstration of a large impact of the strength of the HRM system on general organizational performance and innovation performance. This concept not only includes the reliability and 
consistency of HR practices, by translating organizational strategy into individual goals, but also assumes a higher level of involvement of the HRM function in the strategy development phase. It highlights the strategic role of HRM and its contribution to competitive advantage. It also emphasizes several process characteristics that help employees and managers create strong beliefs concerning organizational goals. According to Bowen and Ostroff, these features include distinctiveness, consistency and consensus. To foster distinctiveness, HRM practices must be salient, unambiguous, invested with status and allow for cause-effect attributions. Consistency, on the other hand, is fostered by instrumentalities and substantive results, while consensus stems from equity of the system and top management support. These metafeatures are present in some new methods for measuring and managing organizational performance, such as the Balanced Scorecard methodology (Kaplan \& Norton, 1992).

The strength of the HRM system may be expected to guarantee the different types of fit that have been emphasized in the literature - vertical and horizontal fit (Wright \& Snell, 1998), in order to meet the needs of changing environments by building flexible organizational competencies.

\section{Limitations of the study}

Several limitations must be reported in this study, starting with the use of survey data with single respondents (Gerhart et al, 2000). Keeping with the methodological problems, mention should be made to the low reliability of three of the variables - innovation as a strategic factor, strategic management orientation and perceived organizational performance. Considering the large sample size in this study, low reliability may have negatively affected the results.

Another limitation derives from the fact that this is not a comparative study; the sample includes companies from 28 different countries, in different continents and it is likely that cultural and institutional differences decrease the significance the results obtained, due to contradictory practices. Further research should distinguish among groups of culturally similar countries and assess whether the model proposed is supported across these groups, or whether this 'American' model applies for some groups and not for other.

Finally, it would have been interesting to introduce variables that theoretically have a negative impact on innovation, such as numerical and contractual 
flexibility, to contrast with the variables used that are aligned with the high performance work systems.

\section{Conclusion}

This research confirms that complementarities across HRM practices positively impact organizational performance. But more importantly, this research suggests that business strategy tends to influence HRM practices, in order to integrate the way organizations respond to their competitive environments, both through the development of corporate strategies and through the internal adaptation for strategy implementation. Organizational performance is shown in this paper to receive the direct impact of the HRM bundles and from the strength of the HRM system, which indicates the internal support of HRM strategy and internal level of commitment to the HRM function.

HRM strength, on the other hand, is dependent of strategic factors, providing a configuration where the different levels are integrated - external environment, competitive strategy, HRM practices and HRM support (Sheppeck \& Militello, 2000). The alignment of the external and internal business environments is proposed to create a synergistic effect in the organizational bottom-line.

Additionally, these results have implications for HRM practitioners, who must not only be sensible to tactical HR practices but also to the relationships among these different components and the system where they are embedded. These forces interact and change over time and only the holistic picture can help HR managers contribute to organizational effectiveness, through effective and efficient HR deliveries, that allow the organization to change and innovate.

\section{REFERENCES:}

Arbuckle, J. \& Wothke, W. (1999), AMOS 4.0, Chicago: SmallWaters Corporation.

Arulampalam, W. \& Booth, A. (1998) "Training and Labour Mraket Flexibility: Is there a Trade Off?", British Journal of Industrial Relations, 36, 521-536.

Barney, J. (1991) "Firm Resources and Sustained Competitive Advantage", Journal of Management, 17, 99-120. 
Barney, J. (1995) "Looking inside for Competitive Advantage", Academy of Management Executive, 9, 49-61.

Bartel, A (1994) "Productivity Gains from the Implementation of Employee Training Programs", Industrial Relations, 33, 411-425.

Becker, B., Huselid, M., Pickus, P. \& Spratt, M. (1997) "HR as a Source of Shareholder Value: Research and Recommendations", Human Resource Management, 36 (1), 39-47.

Bossink, B. (2000) "Innovative quality management practices in the Dutch construction industry", International Journal of Quality and Reliability Management, 19(2): 170-186.

Bowen, D. \& Ostroff, C. (2004) "Understanding HRM-Firm Performance Linkages: The Role of the Strength" of the HRM System", Academy of Management Review, 29 (2), 203-221.

Brewster, C., Mayrhofer, W. \& Morley, M. (2004) Human Resource Management in Europe: Evidence of Convergence?, Oxford, Elsevier.

Browne, M. \& Cudeck, R. (1993) "Alternative ways of assessing model fit", in K.A. Bollen \& J.S. Long (eds.) Testing Structural Equation Models, 66-110, Newbury Park, CA: Sage.

Cottam, A., Ensor, J. \& Band, C. (2001), "A benchmark study of strategic commitment to innovation", European Journal of Innovation Management, 4(2): 88-94.

Cunha, M. P., Kamoche, K., Cunha, R.C., Faia-Correia, M. \& Batista, M.G. (2004) "Organizational Improvisation from an Austrian Perspective", paper presented at CIMOC Inaugural Symposium, Center for Innovation Management and Organizational Change, City University of Hong Kong, June 2-4.

Cunha, R., Cunha, M., Morgado, A. \& Brewster, C. (2003) "Market Forces, Strategic Management, Human Resource Management Practices and Organizational Performance, A Model Based on a European Sample", Management Research, 1 (1), 79-91. 
Damanpour, F., Szabat, K. \& Evan, W. (1989), "The relationship between types of innovation and organizational performance", The Journal of Management Studies, 26(6): 587-601.

Delaney, J. \& Huselid, M. (1996) "The Impact of Human Resource Management Practices on Perceptions of Organizational Performance", Academy of Management Journal, 39, 949-969.

Gerhart, B. \& Trevor, C. (1996) "Employment Variability under Different Managerial Compensation Systems", Academy of Management Journal, 39, 1692-1712.

Gerhart, B., Wright, P., McMahan, G. \& Snell, S. (2000), "Measurement error in research on human resources and firm performance: how much error is there and how does it influence effect size estimates?", Personnel Psychology, 53: 803-833.

Gómez-Mejía, L. (1992) Structure and Process of Diversification, Compensation Strategy, and Firm Performance", Strategic Management Journal, 13, 381-397.

Han, J., Kim, N. \& Srivastava, R. (1998), "Marketing orientation and organizational performance: is innovation a missing link?", Journal of Marketing, 62(4): 30-45.

Huselid, M. (1995) "The Impact of Human Resource Management Practices on Turnover, Productivity and Corporate Financial Performance", Academy of Management Journal, 38, 635-670.

Ichniowski, C., Shaw, K. \& Prennushi, G. (1997) "The Effects of Human Resource Management Practices on Productivity: A Study of Steel Finishing Lines", The American Economic Review, 87 (3), 291-313. 
Kanji, G.K. (1996), “Can total quality management help innovation?”, Total Quality Management, 7(1): 3-9.

Kaplan, R. \& Norton, D. (1992) "The Balanced Scorecard - measures that drive performance", Harvard Business Review, Jan-Feb: 71-79.

Khan, A. M. \& Manopichetwattana, V. (1989), "Innovative and noninnovative small firms: types and characteristics", Management Science, 35(5): 597606.

Koch, M. \& McGrath, R. (1996), "Improving labor productivity: human resource management polices do matter", Strategic Management Journal, 17(5):335-354.

Kogut, B. \& Zander, U. (1992), "Knowledge of the firm, combinative capabilities, and the replication of technology", Organizational Science, 3(3): 383-397.

Lahteenmaki, S. \& Vanhala, S. (1998) "HRM and company performance: the use of measurement and the influence of economic cycles", Human Resource Management Journal, 8: 51-65.

Lam, A. (1996) "Engineers, Management and Work Organization: A Comparative Analysis of Engineers' Work Roles in British and Japanese Electronics Firms", Journal of Management Studies, 33 (2)

Laursen, K. \& Foss, N.J. (2003) "New Human Resource Management Practices, Complementarities and the Impact on Innovation Performance", Cambridge Journal of Economics, 2003, 27, 243-263.

Lyles, M., Baird, I., Orris, B. \& Kuratko, D. (1993), "Formalized planning in small business: increasing strategic choices", Journal of Small Business Management, 31: 38-48.

MacDuffie, J. (1995) "Human Resource Bundles and Manufacturing Performance: Organizational Logic and Flexible Production Systems in the World Auto Industry", Industrial and Labor Relations Review, 48 (2), 197-221.

Martell, K. \& Carroll, S. J. (1995) "Which executive human resource management practices for top management are associated with higher firm performance?", Human Resource Management, 34: 497-512. 
McDonald, D. \& Smith, A. (1995) "A Proven Connection: Performance Management and Business Results", Compensation and Benefits Review, January-February, 59-64.

Murphy, K. \& Davidshofer, C. (1988), Psychological testing: Principles and Applications, Englewood Cliffs, NJ: Prentice-Hall.

Nayak, P. (1991), "Forces driving rapid technological development", Marketing Intelligence \& Planning, 9(5): 29-39.

Nunnally, J. (1967), Psychometric Theory, New York: McGraw-Hill.

O’Brien, J.P. (2003) "The Capital Structure Implications of pursuing a Strategy of Innovation", Strategic Management Journal, 24(5): 415-431.

Pavitt, K. (1991) "Key Characteristics of the Large Innovating Firm", British Journal of Management, 2 (1), 41-50.

Pearce, J., Robbins, D. \& Robinson, R. (1987) "The impact of grand strategy and planning formality on financial performance", Strategic Management Journal, 8: 125-135.

Scarbrough, H. \& Corbett, J. (1992), Technology and Organization: Power, Meaning and Design, London: Routledge.

Schneider, B., Brief, A. P. \& Guzzo, R. A. (1996) "Creating a Climate and Culture for Sustainable Organizational Change" Organizational Dynamics, 24(4), 7-19.

Scott, S. \& Bruce, R. (1994), "Determinants of innovative behavior: a path model of individual innovation in the workplace", Academy of Management Journal, 37(3): 580-607.

Sheppeck, M. \& Militello, J. (2000), "Strategic HR configurations and organizational performance", Human Resource Management, 39(1): 5-16.

Storey, J., Quintas, P., Taylor, P. \& Fowle, W. (2002) "Flexible Employment Contracts and their Implications for Product and Process Innovation", International Journal of Human Resource Management, 13 (1), 1-18. 
Tregaskis, O. (1997), "The role of national context and HR strategy in shaping training and development practice in French and UK organizations", Organization Studies, 18: 839-856.

Van de Ven, A. H. (1986) "Central problems in the management of innovation", Management Science, 32: 590-607.

Weick, K. (1993), "The collapse of sensemaking in organizations: The Mann Gulch disaster", Administrative Science Quarterly, 38(4): 628-652.

Wright, P. \& Snell, S. (1998) "Toward a Unifying Framework for exploring Fit and Flexibility in Strategic Human Resource Management", Academy of Management Review, 23 (4), 756-772. 


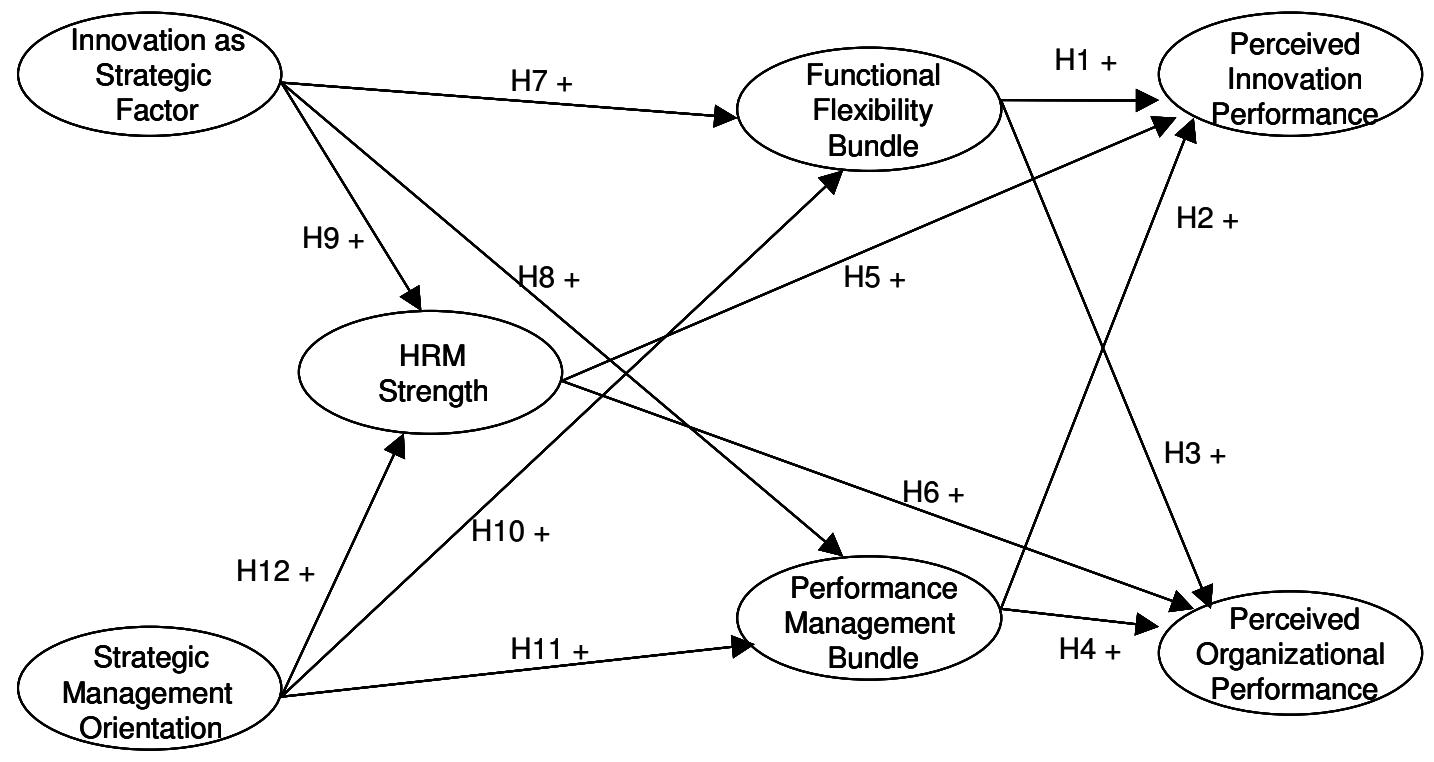

Fig.1 - Proposed model of Impact of HRM Bundles and HRM Strength on Innovation and Organizational Performance. 


\begin{tabular}{|c|c|c|}
\hline Country & $\mathbf{N}$ & $\%$ \\
\hline United Kingdom & 272 & 14.9 \\
\hline France & 137 & 7.5 \\
\hline Germany & 134 & 7.4 \\
\hline Sweden & 100 & 5.5 \\
\hline Spain & 71 & 3.9 \\
\hline Denmark & 117 & 6.4 \\
\hline The Netherlands & 41 & 2.3 \\
\hline Italy & 13 & 0.7 \\
\hline Switzerland & 51 & 2.8 \\
\hline Turkey & 28 & 1.5 \\
\hline Ireland & 75 & 4.1 \\
\hline Portugal & 33 & 1.8 \\
\hline Finland & 83 & 4.6 \\
\hline East Germany & 25 & 1.4 \\
\hline Greece & 13 & 0.7 \\
\hline Czech Republic & 47 & 2.6 \\
\hline Austria & 47 & 2.6 \\
\hline Belgium & 89 & 4.9 \\
\hline Bulgaria & 5 & 0.3 \\
\hline Japan & 166 & 9.1 \\
\hline Australia & 85 & 4.7 \\
\hline Cyprus & 4 & 0.2 \\
\hline Israel & 23 & 1.3 \\
\hline Tunisia & 3 & 0.1 \\
\hline South Africa & 9 & 0.5 \\
\hline Northern Ireland & 35 & 1.9 \\
\hline Taiwan & 91 & 5.0 \\
\hline Estonia & 25 & 1.4 \\
\hline Total & 1822 & 100 \\
\hline
\end{tabular}

Table 1 - Distribution of sample by country 


\begin{tabular}{|l|c|c|}
\hline Sector & N & $\%$ \\
\hline Manufacturing and other industry & 1177 & 65 \\
\hline Services & 645 & 35 \\
\hline
\end{tabular}

Table 2 - Distribution of sample by sector of activity

\begin{tabular}{|l|c|c|}
\hline Latent Variables & \# of items & $\begin{array}{c}\text { Cronbach's } \\
\text { alpha }\end{array}$ \\
\hline$\eta_{1}$ HRM Strength & 17 & 0.78 \\
\hline$\eta_{2}$ Functional Flexibility Bundle & 19 & 0.84 \\
\hline$\eta_{3}$ Performance Management Bundle & 7 & 0.80 \\
\hline$\eta_{4}$ Perceived Innovation Performance & 3 & 0.70 \\
\hline$\eta_{5}$ Perceived Organizational Performance & 2 & 0.64 \\
\hline$\xi_{1}$ Innovation as Strategic Factor & 8 & 0.61 \\
\hline$\xi_{2}$ Strategic Management Orientation & 6 & 0.66 \\
\hline
\end{tabular}

Table 3 - Reliability of variables 


\begin{tabular}{|c|c|c|c|c|c|c|c|c|c|c|c|}
\hline Item & Variable & $\begin{array}{l}\text { Para } \\
\text { meter }\end{array}$ & Estimate & s.e. & $t$ & Item & Variable & Parameter & Estimate & s.e. & $t$ \\
\hline $\begin{array}{l}\text { Pay policy } \\
\text { existence }\end{array}$ & HRM strength & 1 & & & & $\begin{array}{l}\text { Tna:employ } \\
\text { ee request }\end{array}$ & $\begin{array}{l}\text { F.Flex. } \\
\text { Bundle }\end{array}$ & $\lambda_{31}$ & 7.50 & 0.78 & $9.57^{* *}$ \\
\hline $\begin{array}{l}\text { Rec/selec. } \\
\text { Policy exist }\end{array}$ & HRM strength & $\lambda_{1}$ & 1.48 & 0.15 & $9.64^{\star \star}$ & Immed.eval. & $\begin{array}{l}\text { F.Flex. } \\
\text { Bundle }\end{array}$ & $\lambda_{32}$ & 5.39 & 0.61 & $8.80^{* *}$ \\
\hline $\begin{array}{l}\text { Train. Policy } \\
\text { existence }\end{array}$ & HRM strength & $\lambda_{2}$ & 1.41 & 0.14 & $9.98^{\star \star}$ & $\begin{array}{l}\text { Eval. } \\
\text { Months later }\end{array}$ & $\begin{array}{l}\text { F.Flex. } \\
\text { Bundle }\end{array}$ & $\lambda_{33}$ & 3.12 & 0.38 & $8.17^{\star \star}$ \\
\hline $\begin{array}{l}\text { Comm.policy } \\
\text { existence }\end{array}$ & HRM strength & $\lambda_{3}$ & 2.34 & 0.23 & $10.01^{* \star}$ & $\begin{array}{l}\text { Training } \\
\text { eval. criteria }\end{array}$ & $\begin{array}{l}\text { F.Flex. } \\
\text { Bundle }\end{array}$ & $\lambda_{34}$ & 5.51 & 0.63 & $8.72^{\star \star}$ \\
\hline $\begin{array}{l}\text { E.Opp.policy } \\
\text { existence }\end{array}$ & HRM strength & $\lambda_{4}$ & 2.07 & 0.23 & $9.07^{\star \star}$ & $\begin{array}{l}\text { Incentives } \\
\text { clerical }\end{array}$ & $\begin{array}{l}\text { Perf.Manag. } \\
\text { Bundle }\end{array}$ & 1 & & & \\
\hline $\begin{array}{l}\text { Flex. policy } \\
\text { existence }\end{array}$ & HRM strength & $\lambda_{5}$ & 1.78 & 0.21 & $8.38^{\star \star}$ & $\begin{array}{l}\text { Incentives } \\
\text { Manual }\end{array}$ & $\begin{array}{l}\text { Perf.Manag. } \\
\text { Bundle }\end{array}$ & $\lambda_{35}$ & 0.80 & 0.25 & $31.34^{\star \star}$ \\
\hline $\begin{array}{l}\text { Man.Dev. } \\
\text { policy exist. }\end{array}$ & HRM strength & $\lambda_{6}$ & 2.84 & 0.26 & $10.79^{\star \star}$ & $\begin{array}{l}\text { Incentives } \\
\text { Tech/Prof. }\end{array}$ & $\begin{array}{l}\text { Perf.Manag. } \\
\text { Bundle }\end{array}$ & $\lambda_{36}$ & 1.25 & 0.06 & $21.23^{\star \star}$ \\
\hline $\begin{array}{l}\text { Pay policy } \\
\text { formaliz. }\end{array}$ & HRM strength & $\lambda_{7}$ & 2.33 & 0.20 & $11.76^{\star \star}$ & $\begin{array}{l}\text { Incentives } \\
\text { Managers }\end{array}$ & $\begin{array}{l}\text { Perf.Manag. } \\
\text { Bundle }\end{array}$ & $\lambda_{37}$ & 1.15 & 0.06 & $18.78^{\star \star}$ \\
\hline $\begin{array}{l}\text { Rec/selec. } \\
\text { Policy formaliz. }\end{array}$ & HRM strength & $\lambda_{8}$ & 3.26 & 0.31 & $10.58^{\star \star}$ & $\begin{array}{l}\text { Obj. Perf. } \\
\text { Appraisal }\end{array}$ & $\begin{array}{l}\text { Perf.Manag. } \\
\text { Bundle }\end{array}$ & $\lambda_{38}$ & 0.40 & 0.06 & $7.33^{\star \star}$ \\
\hline $\begin{array}{l}\text { Comm.policy } \\
\text { formaliz. }\end{array}$ & HRM strength & $\lambda_{10}$ & 3.03 & 0.29 & $10.30^{\star \star}$ & $\begin{array}{l}\text { Categ. w/ } \\
\text { perf.appr. }\end{array}$ & $\begin{array}{l}\text { Perf.Manag. } \\
\text { Bundle }\end{array}$ & $\lambda_{40}$ & 0.37 & 0.04 & $9.50^{\star \star}$ \\
\hline $\begin{array}{l}\text { E.Opp.policy } \\
\text { formaliz. }\end{array}$ & HRM strength & $\lambda_{11}$ & 1.93 & 0.23 & $8.36^{\star \star}$ & $\begin{array}{l}\text { Quality } \\
\text { performance }\end{array}$ & $\begin{array}{l}\text { Innovation } \\
\text { Performance }\end{array}$ & 1 & & & \\
\hline $\begin{array}{l}\text { Flex. policy } \\
\text { formaliz. }\end{array}$ & HRM strength & $\lambda_{12}$ & 2.27 & 0.25 & $9.06^{* *}$ & $\begin{array}{l}\text { Prod.to } \\
\text { market perf. }\end{array}$ & $\begin{array}{l}\text { Innovation } \\
\text { Performance }\end{array}$ & $\lambda_{41}$ & 1.93 & 0.12 & $15.91^{* *}$ \\
\hline $\begin{array}{l}\text { Man.Dev. } \\
\text { policy } \\
\text { formaliz.. }\end{array}$ & HRM strength & $\lambda_{13}$ & 4.01 & 0.36 & $11.17^{\star \star}$ & $\begin{array}{l}\text { Innovation } \\
\text { performance }\end{array}$ & $\begin{array}{l}\text { Innovation } \\
\text { Performance }\end{array}$ & $\lambda_{42}$ & 1.89 & 0.12 & $16.20^{\star \star}$ \\
\hline
\end{tabular}

Table 4 - Indicator Loadings 
Table 4 - Indicator Loadings (Cont.)

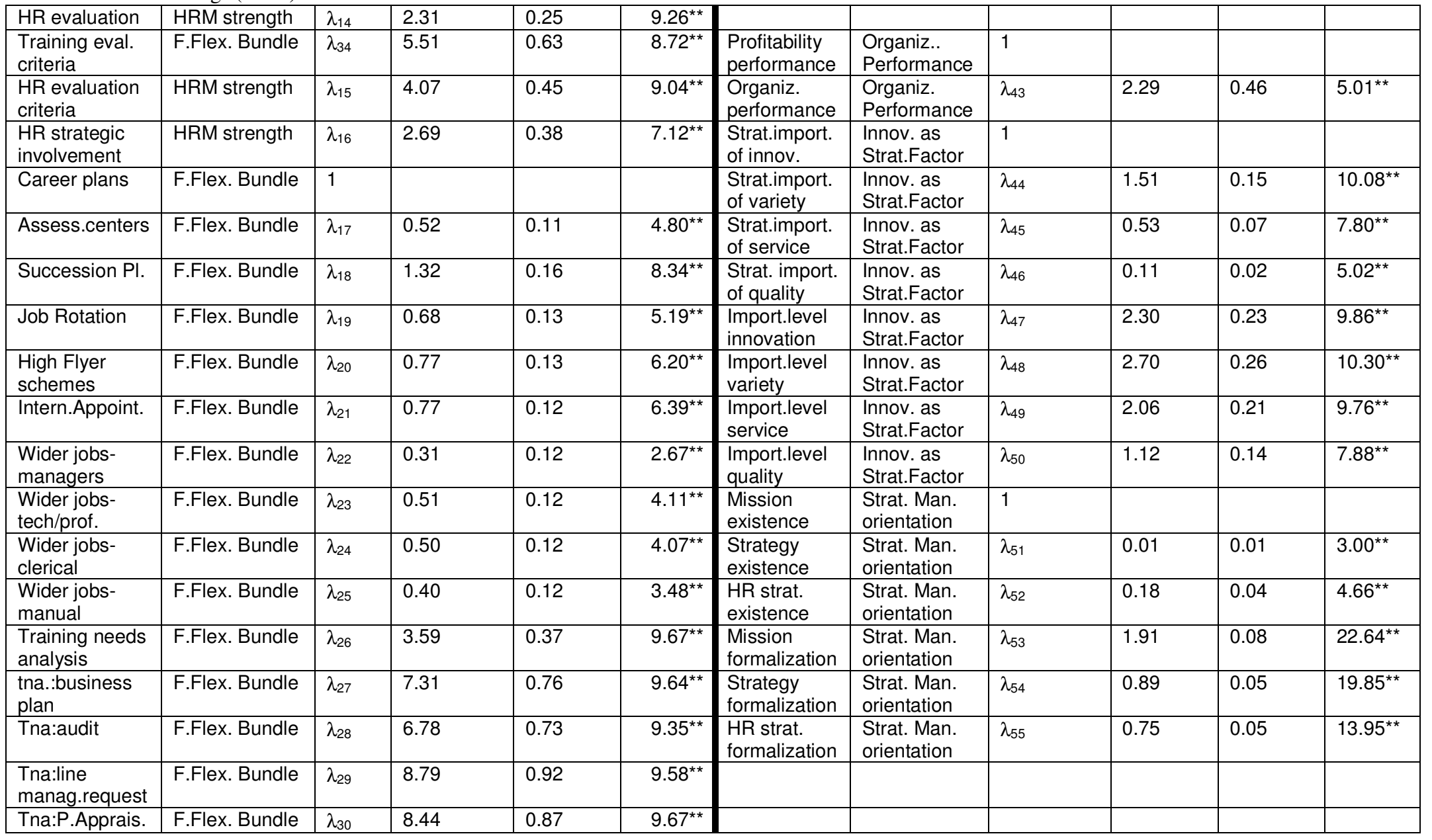




\begin{tabular}{|c|c|c|c|c|c|}
\hline $\begin{array}{c}\text { Latent } \\
\text { Variables }\end{array}$ & $\begin{array}{c}\text { Innovation } \\
\text { as Strategic } \\
\text { Factor } \\
\xi_{1}\end{array}$ & $\begin{array}{c}\text { Strategic } \\
\text { Management } \\
\text { Orientation } \\
\xi_{2}\end{array}$ & $\begin{array}{c}\text { HRM } \\
\text { Strength } \\
\eta_{1}\end{array}$ & $\begin{array}{c}\text { Functional } \\
\text { Flexibility } \\
\text { Bundle } \\
\eta_{2}\end{array}$ & $\begin{array}{c}\text { Performance } \\
\text { Management } \\
\text { Bundle } \\
\eta_{3}\end{array}$ \\
\hline HRM Strength $\eta_{1}$ & $\begin{array}{l}0.140 \\
\left(3.90^{\star \star}\right) \\
\end{array}$ & $\begin{array}{l}0.285 \\
\left(7.93^{\star \star}\right) \\
\end{array}$ & & & \\
\hline $\begin{array}{l}\text { Functional } \\
\text { Flexibility Bundle } \\
\eta_{2}\end{array}$ & $\begin{array}{l}0.105 \\
\left(3.14^{\star \star}\right) \\
\end{array}$ & $\begin{array}{l}0.209 \\
\left(6.37^{\star \star}\right) \\
\end{array}$ & & & \\
\hline $\begin{array}{l}\text { Performance } \\
\text { Management } \\
\text { Bundle } \eta_{3}\end{array}$ & $\begin{array}{l}0.008 \\
(0.24) \\
\end{array}$ & $\begin{array}{l}0.060 \\
\left(2.41^{*}\right)\end{array}$ & & & \\
\hline $\begin{array}{l}\text { Innovation } \\
\text { Performance } \eta_{4}\end{array}$ & & & $\begin{array}{l}0.206 \\
\left(5.95^{\star \star}\right)\end{array}$ & $\begin{array}{l}0.030 \\
(1.12)\end{array}$ & $\begin{array}{l}-0.024 \\
(-0.86)\end{array}$ \\
\hline $\begin{array}{l}\text { Perceived } \\
\text { Organizational } \\
\text { Performance } \eta_{5}\end{array}$ & & & $\begin{array}{l}0.097 \\
\left(2.81^{\star \star}\right)\end{array}$ & $\begin{array}{l}0.117 \\
\left(3.23^{\star \star}\right)\end{array}$ & $\begin{array}{l}0.110 \\
\left(3.33^{\star \star}\right)\end{array}$ \\
\hline
\end{tabular}

$$
t^{\star}-p<0.05 ; t^{\star \star}-p<0.01
$$

Table 5 - Results by Maximum Likelihood - Path Coefficients and (t-values) 


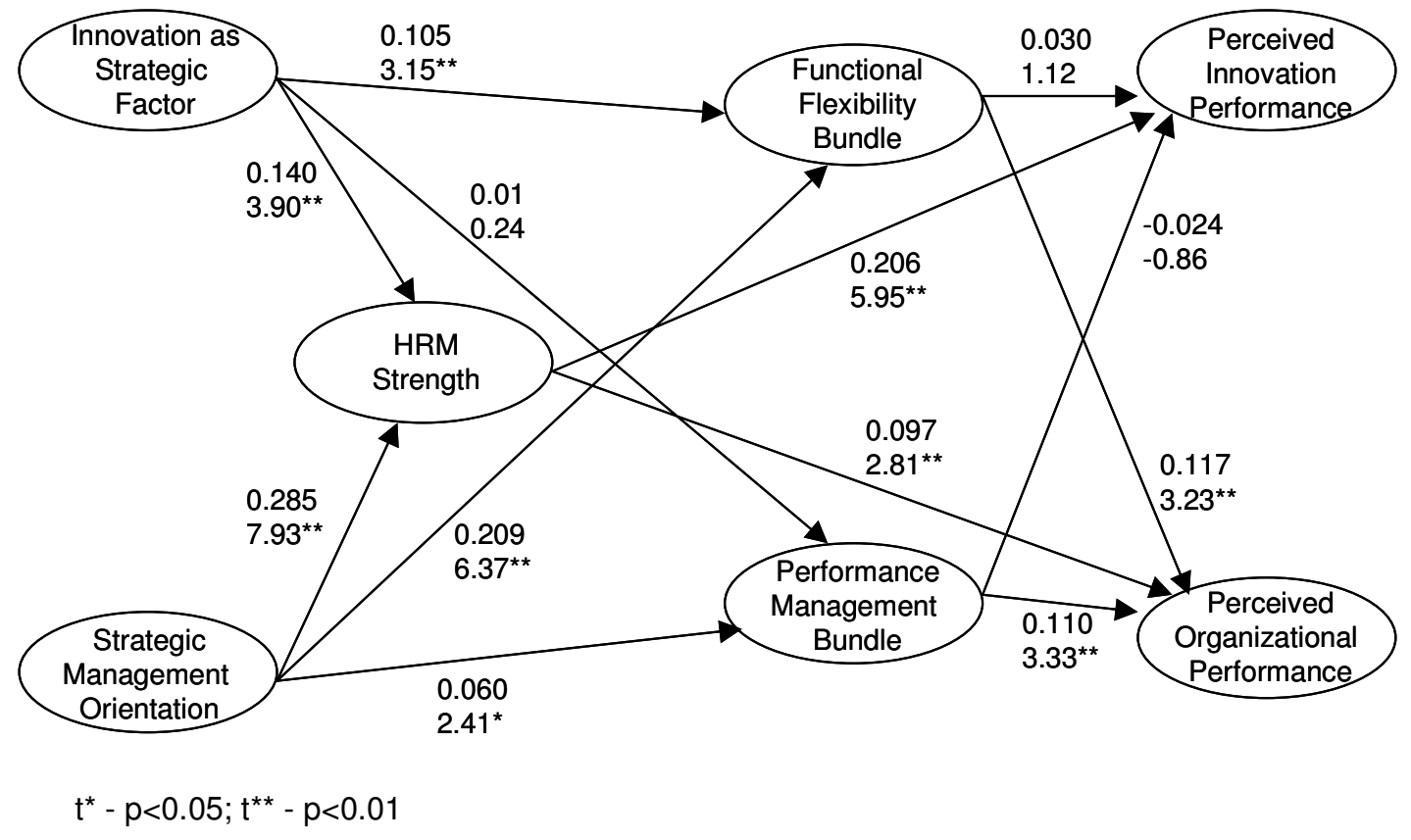

Figure 2 - Paths coefficients between latent variables and (t-values) 
